\title{
DIANA DAJNOWICZ
}

\section{Konferencja naukowa „Kobiety - polityka - prawo - dyskurs publiczny" (Augustów, 15-16 października 2015 r.)}

W dniach 15-16 października 2015 r. w Hotelu Wojciech w Augustowie odbyła się konferencja naukowa „Kobiety - polityka - prawo - dyskurs publiczny", poświęcona takim zagadnieniom, jak miejsce kobiet w polityce i dyskursie publicznym oraz wpływ wykładni prawnej i zmian prawnych na możliwości udziału kobiet w życiu publicznym. Konferencja była IV spotkaniem naukowym z cyklu „Kobiety w życiu publicznym” ${ }^{1}$. Wśród organizatorów tej inicjatywy naukowej znaleźli się: stowarzyszenie Instytut Studiów Kobiecych, Zakład Ruchów Społecznych i Politycznych Instytutu Historii i Nauk Politycznych Uniwersytetu w Białymstoku oraz Książnica Podlaska im. Łukasza Górnickiego, zaś Marszałek Województwa Podlaskiego objął konferencję honorowym patronatem. Organizacja konferencji współfinansowana była przez województwo podlaskie.

Merytoryczną debatę poprzedziło otwarcie konferencji i oficjalne powitanie przybyłych gości i referentów przez dr hab. prof. UwB Małgorzatę Dajnowicz, kierownika Zakładu Ruchów Społecznych i Politycznych UwB. Profesor Małgorzata Dajnowicz w sposób szczególny przywitała przybyłą z Uniwersytetu Jana Kochanowskiego w Kielcach prof. dr hab. Jolantę Chwastyk-Kowalczyk, podkreślając jej liczne osiągnięcia i sukcesy naukowe w zakresie literaturoznawstwa oraz bibliologii. Następnie wyraziła przekonanie, iż tematy prezentowanych referatów wywołają zainteresowanie wśród uczestników konferencji i zapowiedziała wystąpienie pierwszego z prelegentów z panelu doktoranckiego.

1 I spotkanie z cyklu Kobiety $w$ życiu publicznym miało tytuł Kobiety $w$ politycznej przestrzeni regionalnej i odbyło się 29 marca 2012 r., II seminarium naukowe traktowało na temat Kobiety w mediach. Dziennikarki, publicystki, twórczynie przekazów medialnych - odbyło się 13 marca 2013 r., III sympozjum naukowe pt. Kobiety $i$ ich wizerunek w sferze publicznej. Polska na tle krajów zachodnich zorganizowane zostało 4 lipca 2014 r. 
Referat pt. Zagadnienia praw kobiet na łamach czasopism kobiecych "Kobiety $i$ Życia" $i$ "Filipinki”, rozpoczynający merytoryczną część spotkania, wygłoszony został przez mgr Urszulę Ćwik, słuchaczkę II roku studiów doktoranckich na Wydziale Historyczno-Socjologicznym Uniwersytetu w Białymstoku. Badaczka w swoim wystąpieniu zwróciła uwagę, iż do lat osiemdziesiątych zagadnienia praw kobiet pojawiały się na łamach czasopism kobiecych jedynie wówczas, gdy zgodę na to wyrażały władze Polskiej Rzeczpospolitej Ludowej. Wskazała także, że temat praw kobiet najczęściej podejmowano przy okazji relacji i sprawozdań medialnych z konkretnych wydarzeń, a jako przykład wymieniła relacje ze Zjazdów Ligi Kobiet czy Rozmów na Szczycie Organizacji Narodów Zjednoczonych. Prelegentka podsumowała swój referat wnioskiem, iż od 1956 do 1980 r. tematyka praw kobiet na łamach prasy gościła dość rzadko, najczęściej poruszana w kontekście życia ekonomicznego i społecznego kobiety, jej pracy, wyboru zawodu oraz dostępu do awansu, jak również silnie akcentowano prawo do autonomii i integralności cielesnej (zwłaszcza w czasopiśmie „Kobieta i Życie”).

Drugi referat nt. Kobiety i polityka w świetle opinii prasowych wybranych tygodników (,Polityka”, "Newsweek”, „Wprost”) zaprezentowała mgr Justyna Zajko-Czochańska - słuchaczka I roku studiów doktoranckich na Wydziale Historyczno-Socjologicznym Uniwersytetu w Białymstoku. W wystąpieniu przedstawione zostały wyniki analizy artykułów prasowych „Polityki”, „Wprost” oraz "Newsweeka”, której przedmiotem był wizerunek kobiet obecnych na polskiej i zagranicznej scenie politycznej. Prezentacja referentki ukazała słuchaczom wykreowany przez trzy wybrane czasopisma obraz kobiety odnoszącej sukces w życiu publicznym, piastującej wysokie stanowiska państwowe i pełniącej funkcje dyplomatyczne. Prelegentka podkreśliła następnie, że na łamach wszystkich trzech pism opis kobiecych sylwetek przybierał formę takich gatunków publicystycznych, jak reportaże, felietony oraz wywiady. W uwagach podsumowujących mgr J. Zajko-Czochańska, na podstawie analizy przekazów prasowych sformułowała wniosek, że wraz z upływam lat wzrasta liczba kobiet uczestniczących w życiu politycznym, jak również zauważalna jest $\mathrm{w}$ tej sferze zmiana jakościowa $\mathrm{w}$ postaci zajmowania przez kobiety coraz wyższych stanowisk. W podsumowaniu wystąpienia doktorantka podkreśliła, że prasa coraz silniej eksponuje problematykę kobiecą, ponieważ dąży do zmiany funkcjonującego stereotypu, iż priorytetową rolą kobiety jest dbanie o dom i rodzinę, nie zaś rozwijanie swojej kariery w życiu publicznym.

Trzecie wystąpienie w panelu doktoranckim zatytułowane Wizerunek kobiet na tamach pisma "Kobieta i Biznes. Międzynarodowe Forum Kobiet” zostało 
zaprezentowane przez mgr Ewę Joannę Borodzicz, absolwentkę kierunku stosunki międzynarodowe na Wydziale Historyczno-Socjologicznym Uniwersytetu w Białymstoku. W swoim referacie prelegentka przedstawiła zagadnienie wizerunku kobiety przedsiębiorczej, który kreowany był na łamach poddanego analizie czasopisma. Dzięki przeprowadzonemu badaniu periodyku mgr E. J. Borodzicz zaprezentowała postać kobiety na stanowisku kierowniczym jako osoby konkretnej $\mathrm{w}$ dążeniach, profesjonalnej $\mathrm{w}$ wykonywanych zadaniach, zajmującej funkcje kierownicze oraz dbającej jednocześnie o swoich podwładnych i zachęcającej pracowników do czynnego uczestnictwa w szeroko rozumianym życiu firmy. W artykułach publikowanych w czasopiśmie „Kobieta i Biznes. Międzynarodowe Forum Kobiet” referentka dostrzegła, iż postać kobieca bardzo często dąży do stworzenia w miejscu pracy atmosfery przyjaznej i sprzyjającej zacieśnianiu więzi międzyludzkich. Kończąc swoją prezentację prelegentka zaakcentowała, że na łamach analizowanego pisma silnie lansowano nowy kobiecy wzorzec, przypisywany nielicznej grupie kobiet aktywnych zawodowo - businesswoman, których cechami charakterystycznymi pozostają energiczność, przedsiębiorczość, zdolność do podejmowania ryzyka oraz konsekwencja w dążeniu do wyznaczonych z góry celów zawodowych.

Kolejnym mówcą była doktorantka IV roku studiów na Wydziale Historyczno-Socjologicznym Uniwersytetu w Białymstoku, mgr Ewa Wiazowska-Lickiewicz, która przedstawiła referat nt. Kobiety w lokalnej polityce a ustawa kwotowa. W swojej prezentacji poruszyła zagadnienie dotyczące uwarunkowań oraz wpływu płci na udział w życiu politycznym, a także przedstawiła porównanie uczestnictwa kobiet $w$ wyborach samorządowych z 2010 i $2014 \mathrm{r}$. w województwie podlaskim na poziomie powiatów oraz miast na prawach powiatu. Prelegentka podzieliła się ze słuchaczami wnioskami z analizy statystycznej, wskazując, iż ustawa kwotowa wpłynęła na zwiększenie liczby kobiet na listach wyborczych większości partii, jednak nie znalazło to odzwierciedlenia w wynikach wyborów (liczba zdobytych mandatów w poszczególnych powiatach nie zmieniła się bowiem w sposób znaczący). Magister E. Wiazowska-Lickiewicz dostrzegła jednak pewne pozytywne zmiany, którym bieg nadało m.in. wprowadzenie ustawy kwotowej. Zdaniem prelegentki, mimo iż społeczeństwo dostrzega, że kobiety potrafią osiągać sukcesy na polu zawodowym (w tym politycznym), nadal widzi się potrzebę przeciwdziałania stereotypowemu myśleniu o kobietach. Kończąc swoje wystąpienie doktorantka podkreśliła, że na poziomie regionalnego politycznego uczestnictwa kobiet i w budowaniu ich karier politycznych nadal widzi się konieczność współdziałania w tym zakresie partii poli- 
tycznych oraz organizacji pozarządowych, promujących udział kobiet w życiu publicznym.

Kolejny referat pt. Niewidoczna obecność? Strategie organizowania się i uwidaczniania zawodowego środowiska prawniczek. Na przykładzie polskim i niemieckim w I połowie XX wieku autorstwa dr Iwony Dadej z Freie Universität w Berlinie dotyczył rzeczywistości społecznej funkcjonowania zawodowego pierwszych prawniczek, które od początku XX w. stanowiły rosnącą liczebnie grupę studiujących na wydziałach prawniczych i z biegiem pierwszych dekad XX w. stały się widocznymi protagonistkami dyskusji nad statusem kobiet $\mathrm{w}$ społeczeństwie, społecznościach zawodowych i kolektywach myślowych. Centralnym zagadnieniem $\mathrm{w}$ referacie stało się przedstawienie procesu kształtowania się społeczności prawniczek na niemieckich, szwajcarskich oraz polskich uniwersytetach. Doktor I. Dadej poruszyła kwestię kształtowania się grupy zawodowej prawniczek w okresie międzywojennym w Republice Weimarskiej oraz II Rzeczpospolitej, gdzie walka o dostęp do zawodów prawniczych oraz samoorganizowanie się $\mathrm{w}$ celu walki o interesy zawodowe były szczególnie widoczne. Prelegentka zainteresowała słuchaczy również licznymi wątkami biograficznymi, przedstawiającymi czołowe inicjatorki ruchu zrzeszeniowego prawniczek i ich trajektorie zawodowe.

Ostatnie wystąpienie w panelu doktoranckim przedstawiła mgr Diana Dajnowicz, doktorantka II roku studiów na Wydziale Prawa Uniwersytetu w Białymstoku, wygłaszając referat pt. Kobiety i porwania rodzicielskie w świetle polskiego dyskursu publicznego. W swojej prelekcji referentka poruszyła zagadnienie roli, jaką pełni kobieta $\mathrm{w}$ obliczu zetknięcia się ze zjawiskiem porwania rodzicielskiego, czyli sytuacji, w której jedno z rodziców bez woli i wiedzy drugiego z nich wywozi lub zatrzymuje dziecko, pozbawiając tym samym drugiego rodzica możliwości utrzymywania kontaktu z małoletnim. Prelegentka przedmiotową problematykę omówiła w oparciu o analizę dyskursu medialnego, zawężonego, z uwagi na dyscyplinę czasową wystąpienia, do informacji przekazywanych na łamach serwisu informacyjno-publicystycznego gazeta.pl. Doktorantka wskazała, że kobietę będącą ofiarą porwania rodzicielskiego charakteryzuje wytrwałość w poszukiwaniach dziecka i dążeniach do jego odzyskania. Odnosząc się natomiast do kobiety będącej sprawcą porwania, referentka nadmieniła, iż często jest ona postrzegana pozytywnie, czemu towarzyszy umniejszanie szkodliwości społecznej realizowanego czynu zabronionego. Kończąc swoje wystąpienie młoda badaczka podkreśliła, iż przeprowadzona analiza wiadomości, artykułów i reportaży ukazała, że porwania rodzicielskie postrzega się jedynie jako dramat matki bądź ojca, zapo- 
minając przy tym o dobru dzieci traktowanych w tego rodzaju przypadkach przedmiotowo.

Po przedstawieniu wszystkich referatów w sesji doktoranckiej nastąpiła dyskusja, w której udział wzięli zaproszeni goście i uczestnicy konferencji. Jako pierwsza głos zabrała prof. dr hab. Jolanta Chwastyk-Kowalczyk, która szczegółowo odniosła się do każdego referatu zaprezentowanego kolejno przez wszystkie młode badaczki naukowe. Profesor J. Chwastyk-Kowalczyk doceniała prelegentki, biorąc pod uwagę tematykę podjętą w wystąpieniach oraz jednocześnie podzieliła się z nimi cennymi uwagami merytorycznymi w celu udoskonalenia ich umiejętności badawczo-naukowych oraz warsztatowych. Następną dyskutantką była dr hab. prof. UwB Małgorzata Dajnowicz, która również bardzo skrupulatnie odniosła się do każdego z wystąpień w panelu doktoranckim, wyróżniając ich mocne strony oraz elementy wymagające dopracowania.

Po zakończeniu dyskusji uczestnicy konferencji przystąpili do drugiej merytorycznej jej części, którą stanowił panel profesorski. Pierwszą prelegentką we wspomnianej sesji była prof. dr hab. Jolanta Chwastyk-Kowalczyk z Instytutu Dziennikarstwa i Informacji Uniwersytetu Jana Kochanowskiego w Kielcach, która wygłosiła referat pt. Dziennikarka polskiej przestrzeni publicznej na emigracji w Londynie - Stefania Kossowska. Na wstępie przypomniała, iż wraz z odzyskaniem przez Polskę niepodległości w 1918 r. nastąpił intensywny rozwój we wszystkich dziedzinach życia politycznego, społecznego, gospodarczego, naukowego, kulturalnego. Prelegentka podkreśliła także, iż okres dwudziestolecia międzywojennego w Polsce wyznaczał nowe standardy zachowań kobiety-obywatelki, kobiety-matki, kobiety-żony, a przyczyniały się do tego przekształcenia społeczno-polityczno-prawne, entuzjastycznie wspomagane przez prasę kobiecą, m.in. Towarzystwa Wydawniczego „Bluszcz”. W czasie tych przemian urodziła się Stefania Kossowska - bohaterka referatu. Prelegentka przybliżyła słuchaczom tę wyjątkową postać kobiecą, podkreślając, iż była ona aktywną animatorką polskiego życia intelektualnego na emigracji. Wskazała, że S. Kossowska była kobietą dojrzewającą w Polsce niepodległej, poddaną ciężkiej próbie wojennej tułaczki oraz podejmującą po zakończeniu drugiej wojny światowej dramatyczne decyzje o pozostaniu na obczyźnie. Profesor J. Chwastyk-Kowalczyk podsumowała bohaterkę swojego wystąpienia jako osobę obdarzoną wieloma talentami, która w swojej twórczości dawała doskonałe świadectwo przynależności polskiej kultury do świata zachodniego.

Druga prelegentka panelu profesorskiego, dr hab. prof. UwB Małgorzata Dajnowicz, poświęciła swoje wystąpienie tematowi Kobiety $i$ świat polityki 
w opiniach prasy kobiecej. Przeglad problematyki na podstawie "Zwierciadła". Małgorzata Dajnowicz na wstępie zarysowała sytuację kobiet w strukturach władzy politycznej Polskiej Rzeczpospolitej Ludowej, podkreślając, iż w porównaniu do mężczyzn stanowiły one niewielki odsetek. Następnie prelegentka przedstawiła uczestnikom konferencji rys historyczny czasopisma „Zwierciadło", które po raz pierwszy wydano w 1957 r. jako pismo z zakresu tematyki kobiecej, podtrzymujące i upowszechniające ład peerelowski, związane z organizacją Ligi Kobiet (od 1982 r. Ligi Kobiet Polskich). W swoim wystąpieniu wskazała, że teksty publikowane w "Zwierciadle" miały charakter bardziej ideologiczny, nie prezentowały tematu formalnego udziału kobiet w polityce, pomimo że kobiety dyskutowały na temat świata polityki oraz uczestniczyły w nim poprzez włączanie się $\mathrm{w}$ dyskusje i oceny dotyczące głównie spraw, które były bezpośrednio związane ze sferami życia kobiecego. W dalszej części wystąpienia prof. M. Dajnowicz podkreśliła, iż obraz przedmiotowego zagadnienia na przestrzeni lat zmieniał się, co szczególnie dało się zauważyć w przekazach prasowych z 1988 r., zgodnie z którymi kobiety przestały być usatysfakcjonowane staniem na uboczu, a zamiast tego zaczęły kroczyć w kierunku aktywniejszego uczestnictwa politycznego. Prelegentka w ostatnich kilku zdaniach swojej prezentacji zaakcentowała, iż optymizmem napawały przekazy prasowe, które przedstawiały obraz zdeterminowanej kobiety "drugiego planu", próbującej wyjść z cienia pod koniec lat osiemdziesiątych i podejmującej próby włączania się $\mathrm{w}$ sferę polityki.

Wystąpienie zamykające konferencję poświęcone było tematowi Obraz kobiet polityki na podstawie sondaży Rosyjskiego Centrum Badania Opinii Społecznej przeprowadzonych w latach 2001-2015. Zostało ono wygłoszone przez dr Beatę Goworko-Składanek, pracownika naukowego Wydziału Historyczno-Socjologicznego Uniwersytetu w Białymstoku. Prelegentka rozpoczęła swoje wystąpienie od podkreślenia, iż mimo gwarancji konstytucyjnych równości praw i szans dla obywateli obu płci, Rosjanki wciąż uważają się za pokrzywdzone i dyskryminowane, zwłaszcza w społecznej i politycznej sferze, biorąc pod uwagę najwyższe szczeble władzy politycznej. Nadmieniła również, że od momentu powołania do życia Konstytucji z 1993 r. udział kobiet w I kadencji rosyjskiej Dumy Państwowej kształtował się na poziomie $13,5 \%$, a odsetek ten jest porównywalny do liczby kobiet pełniących funkcje deputowanych w obecnej kadencji Dumy. Referentka zaznaczyła, że najniższy odsetek deputowanych płci żeńskiej był w okresie II kadencji - 6,92\%, zaś najwyższy w V kadencji i wyniósł 15,41\%. Następnie powołała ona przeprowadzony w 2011 r. sondaż, który pokazał, że stosunek Rosjan do obecności kobiet w polityce na przestrzeni 13 lat (1998-2011) 
uległ znacznemu ochłodzeniu, zaś w 2011 r. prawie jedna czwarta respondentów uważała, że liczba kobiet $\mathrm{w}$ polityce powinna być mniejsza lub nie powinno ich być $\mathrm{w}$ ogóle. W podsumowaniu swojego wystąpienia prelegentka zauważyła, iż wysoce niepokojąca jest tendencja Rosjan do marginalizowania uczestnictwa kobiet $\mathrm{w}$ przestrzeni życia publicznego i politycznego.

Po zakończeniu drugiej, profesorskiej, sesji referatowej prelegenci oraz pozostali goście konferencji ponownie przystąpili do dyskusji merytorycznej. Istotną kwestią, którą w uwagach końcowych podkreśliła prof. J. Chwastyk-Kowalczyk, pozostaje formułowanie wniosków z dotychczasowych doświadczeń kobiet i nieustające podejmowanie prób poszukiwania rozwiązań ułatwiających kobietom pokonywanie barier tzw. szklanego sufitu. W ostatnim zdaniu dodała, iż konferencję pt. Kobiety - polityka - prawo - dyskurs publiczny ocenia jako wyjątkowo udane przedsięwzięcie naukowe, zarówno w aspekcie merytorycznym, jak i organizacyjnym, które bez wątpienia będzie stanowić silny impuls do kontynuowania organizacji następnych spotkań z cyklu Kobiety w życiu publicznym.

Czwarte z kolei przedsięwzięcie naukowe z cyklu Kobiety w życiu publicz$n y m$, które zorganizowano w formie konferencji pt. Kobiety - polityka - prawo dyskurs publiczny podsumowała również dr hab. prof. M. Dajnowicz, wymieniając najważniejsze wnioski wynikające $\mathrm{z}$ każdego wygłoszonego referatu oraz dyskusji podsumowującej konferencję.

Diana Dajnowicz, mgr prawa, doktorantka na Wydziale Prawa Uniwersytetu w Białymstoku.

e-mail: ddajnowicz@gmail.com 